\title{
Dental Students' Discomfort and Anxiety During the First and the Second Lockdown Due to COVID-19 Pandemic at the School of Dental Medicine, University of Zagreb
}

\section{Nelagoda i anksioznost studenata dentalne medicine tijekom prvoga i drugoga zaključavanja zbog pandemije COVID-19 na Stomatološkom fakultetu Sveučilišta u Zagrebu}

\author{
${ }^{1}$ School of Dental Medicine, University of Zagreb \\ Stomatološki fakultet Sveučilišta u Zagrebu \\ 2 Independent researcher, Mainz, Germany \\ Neovisni istraživač, Mainz, Njemačka
}

\begin{abstract}
Objectives: The aim of the study was to assess discomfort and anxiety of dental students caused by the COVID-19 pandemic crisis and to assess quality of the study during the crisis, as well as to compare subjective experiences and attitudes of preclinical and clinical students towards lectures and practicals during the first and the second lockdown at the School of Dental Medicine, University of Zagreb. Methods: This research was conducted using online questionnaires. The questionnaires were compiled by students for a presentation at the Brescia Colloquium 2020. The participants were integrated undergraduate and graduate dental students from the School of Dental Medicine, University of Zagreb. The questionnaires were completed by students during March 2020 and during February 2021 and were anonymous. For the statistical analysis of the data, the software package SPSS 20 (IBM Corp., Armonk, New York, USA) was used. Descriptive statistical analysis was used to determine the basic statistical parameters (frequencies, median, mod, minimum and maximum values). The significance of the differences among the tested groups was assessed by the Chi-Square or the Fisher's Exact Tests. Results: All dental students experienced some discomfort and were worried about the future competence. No gender differences were found $(p>0.05)$. Preclinical students were less motivated than clinical students $(p<0,01)$ during first lockdown, while significant differences were found between preclinical and clinical students considering safety, competence and confidence to treat patients during second lockdown. Conclusions: COVID-19 pandemic impacted the wellbeing of the students, their learning and teaching at the School of Dental Medicine, University of Zagreb. Students were more overwhelmed by the pandemic during the first lockdown than during second lockdown and have adapted well to the new forms of teaching. However, they are still uncertain about competency in the clinical environment and their future career.
\end{abstract}

Received: April 262021

Accepted: June 6, 2021

Address for correspondence

Marta Adam, student

Ulica Jurja Žerjavića, 12

10000 Zagreb, Croatia

Phone: +385 951992300

marta.adam@hotmail.com

\section{Introduction}

The aim of the study was to point out the effects of the COVID-19 pandemic on the quality of study and to compare subjective experiences of students of dental medicine during the first and the second lockdown (2020 and 2021, respectively) at the School of Dental Medicine, University of Zagreb.

In December 2019, the first cases of novel coronavirus disease (COVID-19), caused by severe acute respiratory syndrome virus 2 (SARS-CoV-2) were reported in Wuhan, China (1). The outbreak of the COVID-19 rapidly escalated causing the worldwide pandemic, which was declared as such on January 30th, 2020 by the World Health Organisa-
Uvod

Cilj ovog istraživanja bio je upozoriti na posljedice i utjecaj pandemije bolesti COVID-19 na kvalitetu studija i usporediti subjektivna iskustva studenata dentalne medicine tijekom prvoga i drugoga zaključavanja (2020. i 2021.) na Stomatološkom fakultetu Sveučilišta u Zagrebu.

U prosincu 2019. godine u Wuhanu u Kini zabilježeni su prvi slučajevi nove koronavirusne bolesti (COVID-19) prouzročene opasnim virusom akutnoga respiratornoga sindroma 2 (SARS-CoV-2). COVID-19 brzo se proširio i izazvao svjetsku pandemiju koju je Svjetska zdravstvena organizacija (SZO) proglasila 30. siječnja 2020. Pandemija nije utjecala samo na zdravstveni sustav zbog milijuna oboljelih i iznimno 
tion (WHO) (2). The pandemic has impacted not only the health care system, thus causing millions of deaths and global health care crisis, but also the course of education at Universities around the world, which had to either postpone or cancel their activities and/or to switch to alternative teaching and learning methods (online classes) $(3,4)$. The changes in the delivery of the study programme, which were primarily introduced to stop the spread of COVID-19 and thus protect the students of dental medicine, subsequently had an impact on quality of education, as well as on students' subjective experiences (5). The presence of coronavirus within the oral cavity and its spread during clinical work in dental offices has put our profession amongst one of the riskiest professions and has closed clinical practice and education in dental medicine (6). In the study of dental medicine, acquiring clinical skills is needed to carry out dental procedures, which is of utmost importance and heavily depends on practical exercises. In addition to lectures and seminars, the dental medicine study curriculum is composed of preclinical and clinical exercises.

Students of dental medicine were thus considerably affected by the change of teaching and learning methods and the way of work at the clinics. Having lost a significant amount of practical exercises, students' clinical competencies were jeopardised. Furthermore, due to continuous droplet and aerosol-generating procedures, dental students working at the clinics are at higher risk of exposure to the COVID-19, thus appropriate precautionary measures must be taken to prevent and control the spread of the SARS-CoV-2 $(7,8)$.

On March $20^{\text {th }}, 2020$ Croatian government declared closing of all educational institutions, including the School of Dental Medicine, University of Zagreb. Only 12 days later, a complete lockdown was imposed, except for pharmacies and grocery stores (9). In addition, on March $22^{\text {nd }}, 2020 \mathrm{Za}$ greb, the capital of Croatia, was hit by a powerful earthquake with a magnitude of 5.5 according to Richter's scale. Thus, during the first lockdown, the School of Dental Medicine was completely closed all indoor lectures, seminars and practicals. All teaching was delivered online until the end of the academic year 2019/2020.

During the second lockdown, which began on the $26^{\text {th }}$ of November 2020, most schools in Croatia continued to carry out all teaching online due to the pandemic, as well as due to material damage from the earthquake. Nevertheless, the School of Dental Medicine managed to be renovated and managed to provide appropriate protection for all students and employees. Face shields, disposable protective gowns, surgical masks and gloves were provided. Additionally, the classrooms and other rooms were well ventilated and the number of persons in the room was minimized. Consequently, preclinical and clinical exercises were delivered in-person, while lectures and seminars remained online (10).

The objectives of this research were to find out the impact of the COVID-19 pandemic crisis on the students of dental medicine during the first lockdown, and to compare the results of their current experience of studying in terms of their subjective attitudes towards: the COVID-19 situation and its impact on their education, their satisfaction with the current way of the study program being delivered, the amount of pre- mnogo umrlih i nije prouzročila samo globalnu zdravstvenu krizu, nego je poremetila i tijek obrazovanja na sveučilištima diljem svijeta koja su morala ili odgoditi ili otkazati nastavu i/ ili prijeći na alternativno poučavanje i metode učenja (nastava na daljinu) $(3,4)$. Promjene u studijskom programu, koje su uglavnom uvedene da zaustave širenje bolesti COVID-19 i na taj se način zaštite studenti dentalne medicine, naknadno su utjecale na kvalitetu obrazovanja i na subjektivna iskustva studenata (5). Prisutnost koronavirusa u usnoj šupljini i njegovo širenje tijekom kliničkoga rada u stomatološkim ordinacijama uvrstili su našu profesiju u jedno od najrizičnijih zanimanja pa je obustavljen klinički rad te obrazovanje iz dentalne medicine (6). Na studiju dentalne medicine potrebno je steći kliničke vještine radi obavljanja stomatoloških zahvata, što je iznimno važno i uvelike ovisi o praktičnim vježbama. Uz predavanja i seminare, u nastavnom planu i programu dentalne medicine predviđene su i pretkliničke i kliničke vježbe.

Studenti dentalne medicine bili su tako znatno pogođeni promjenom metoda poučavanja i učenja te načina rada na klinikama. Zbog gubitka mnogobrojnih praktičnih vježbi bile su ugrožene njihove kliničke kompetencije. Nadalje, zbog kontinuiranog stvaranja kapljica i aerosola, studenti dentalne medicine koji rade u klinici izloženiji su riziku od koronavirusa te se moraju poduzeti odgovarajuće mjere opreza kako bi se spriječilo i kontroliralo širenje virusa SARS-CoV-2 $(7,8)$.

Hrvatska je vlada 20. ožujka 2020. godine proglasila zatvaranje svih obrazovnih institucija, uključujući i Stomatološki fakultet Sveučilišta u Zagrebu. Samo 12 dana poslije objavljeno je potpuno zaključavanje, osim za ljekarne i trgovine mješovitom robom (9). Uz to, 22. ožujka 2020. Zagreb je pogodio veliki potres magnitude 5,5 (Richterova ljestvica). Tako je tijekom prvoga zaključavanja Stomatološki fakultet bio potpuno zatvoren - nije bilo predavanja, seminara i vježbi. Nastava se održavala na daljinu putem interneta do kraja akademske godine 2019./2020.

Tijekom drugog zaključavanja, koje je počelo 26. studenoga 2020., većina fakulteta u Hrvatskoj nastavila je s predavanjima na daljinu zbog pandemije i materijalne štete nastale u potresu. Ipak, Stomatološki fakultet uspio se obnoviti i pružiti odgovarajuću zaštitu svim studentima i zaposlenicima. Osigurani su štitnici za lice, zaštitna odjeća za jednokratnu upotrebu, kirurške maske i rukavice. Uz to, prostorije su se dobro provjetravale, a broj osoba u njima smanjen je na minimum. Slijedom toga, pretkliničke i kliničke vježbe održavale su se na fakultetu, a predavanja i seminari na daljinu (10).

Ciljevi ovog istraživanja bili su otkriti utjecaj pandemije bolesti COVID-19 na studente dentalne medicine tijekom prvog zaključavanja i usporediti rezultate njihova iskustva kad je riječ o studiranju i subjektivnim osjećajima prema situaciji s bolesti COVID-19 i njezinu utjecaju na njihovo obrazovanje. Željelo se doznati također jesu li zadovoljni trenutačnom provedbom studijskoga programa, količinom pretkliničke/kliničke prakse, svojom sposobnošću u korištenju zaštitne radne opreme (ZRO) tijekom vježbi, ukupnom sigurnošću u pretkliničkom/kliničkom okružju te mogućnošću nadoknade izgubljenih pretkliničkih/kliničkih vježbi i izgledima za zapošljavanje. 
clinical/clinical practice, their competence in using PPE during the preclinical/clinical exercises, overall safety in the preclinical/clinical environment, the possibility of compensating for the lost preclinical/clinical exercises, the prospects of employment.

\section{Materials and methods}

\section{Ethical consideration}

The research, questionnaire and consent statement have been approved by the Ethics Committee of the School of Dental Medicine, University of Zagreb, protocol number 05-PA-30-XXIII-2021.

\section{Study design and data collection}

The research is based on three individual questionnaires that were carried out in May 2020 for Brescia Colloquium and of one additional questionnaire (AQ) which was carried out in February 2021. Three individual questionnaires were designed for third-year students (questionnaire TQ), fourth-year students (questionnaire FQ) and sixth-year students (questionnaire SQ). The results of the respective questionnaires were statistically analysed and compared to see the differences of studying experiences during the first and the second lockdown, and between the preclinical and clinical students and gender. The additional questionnaire (AQ) was composed of 12 questions and was a follow-up to the abovementioned group of questionnaires (TQ, FQ and SQ). The $\mathrm{AQ}$, as well as the TQ, FQ and SQ, were delivered in a form of a Google Form application in February 2021. Dental students were approached with the help of social media for filling in the online questionnaire via link. Twelve questions in the questionnaires were related to students' opinions about studying during the COVID-19 pandemic. Individual opinions were assessed using a 4-point scale (1-Agree, 2-Neutral, 3-Disagree, 4-I don't know). The last question was optional and collected only qualitative data. The questionnaires did not collect any personal data and were filled out voluntarily. The participants of the study gave their online consents to participate in the study by submitting an answer.

\section{Content and Face validity}

The study instrument was validated before being distributed to the study sample. To ensure content validity, the questionnaire was sent out to two academics from the School of Dental Medicine, University of Zagreb, for structured and unstructured feedback and it was later sent to three randomly chosen dental students from the School of Dental Medicine, University of Zagreb, for face validity.

\section{Participants}

The participants were 120 dental students of the School of Dental Medicine, University of Zagreb from the first to the sixth year of the integrated study program. The response rate for AQ was $19 \%$, for TQ 47\%, FQ 42\% and for SQ $40 \%$.

\section{Inclusion criteria}

Undergraduate dental students from the School of Den-

\section{Materijal i metode}

\section{Etičko razmatranje}

Istraživanje, upitnik i izjavu o pristanku odobrilo je Etičko povjerenstvo Stomatološkog fakulteta Sveučilišta u Zagrebu - protokol broj 05-PA-30-XXIII-2021.

\section{Dizajn studije i prikupljanje podataka}

Istraživanje se temelji na trima pojedinačnim upitnicima koji su pripremljeni u svibnju 2020. za Kolokvij u Bresciji u Italiji (Brescia Colloquium) i na jednomu dodatnom (AQ) koji je proveden u veljači 2021. Izrađena su tri pojedinačna upitnika - za studente treće godine (upitnik TQ), četvrte godine (upitnik FQ) i šeste godine (upitnik SQ). Dobiveni rezultati statistički su analizirani i uspoređeni kako bi se vidjele razlike u iskustvima tijekom prvoga i drugoga zaključavanja, zatim između studenata pretkliničke i kliničke nastave te spolova. Dodatni upitnik (AQ) sastoji se od 12 pitanja i nastavak je spomenute skupine upitnika (TQ, FQ i SQ). AQ, te TQ, FQ i SQ dostavljeni su u obliku aplikacije Googlova obrasca. $\mathrm{Za}$ ispunjavanje upitnika putem interneta sa studentima dentalne medicine kontaktiralo se na društvenim mrežama. Dvanaest pitanja odnosilo se na njihovo mišljenje o studiranju tijekom pandemije bolesti COVID-19. Pojedinačna mišljenja ocjenjivana su na temelju ljestvice $s$ četirima točkama (1 - slažem se, 2 - neutralno, 3 - ne slažem se, 4 - ne znam). Posljednje pitanje bilo je neobvezno i prikupljali su samo kvalitativne podatke. $U$ upitnicima nisu bila postavljena pitanja ni o kakvim osobnim podatcima $i$ ispunjavanje je bilo dobrovoljno. Slanjem odgovora sudionici su dali pristanak za sudjelovanje $\mathrm{u}$ istraživanju.

\section{Sadržaj i valjanost lica}

Instrument istraživanja potvrđen je prije distribucije uzorka istraživanja. Da bi se osigurala valjanost sadržaja, upitnik je poslan dvojici akademika sa Stomatološkog fakulteta Sveučilišta u Zagrebu na strukturirane i nestrukturirane povratne informacije, a poslije je, za valjanost lica, dostavljen trojim slučajno odabranim studentima dentalne medicine sa Stomatološkog fakulteta Sveučilišta u Zagrebu.

\section{Sudionici}

Sudjelovalo je 120 studenata Stomatološkog fakulteta Sveučilišta u Zagrebu od prve do šeste godine integriranoga studijskog programa. Stopa odgovora za AQ bila je $19 \%$, za TQ $47 \%$, FQ $42 \%$ i za SQ $40 \%$.

\section{Kriteriji za uključivanje}

Studenti integriranoga dodiplomskoga i diplomskoga 
tal Medicine, University of Zagreb.

\section{Exclusion criteria}

Postgraduate dental students from the School of Dental Medicine, University of Zagreb.

\section{Statistical methods}

For the statistical analysis of the data, the software package SPSS 20 (IBM Corp., Armonk, New York, USA) was used. Descriptive statistical analysis was used to determine the basic statistical parameters (frequencies, median, mod, minimum and maximum values). The significance of the differences among the tested groups was assessed by the ChiSquare or the Fisher's Exact Tests.

\section{Results}

\section{Results from the 2020 questionnaire (Questionnaire $\mathrm{TQ}$ and $\mathrm{FQ})$}

The questionnaires, which included the $3^{\text {rd }}$ and the $4^{\text {th }}$ year students, were answered by 79 dental students. No differences between genders were found ( $p>0.05)$. No differences existed between the preclinical and the clinical students ( $p>0.05)$, except for the motivation since clinical students were significantly more motivated $(p<0,01)$. The results studija dentalne medicine Sveučilišta u Zagrebu.

Kriteriji za isključenje

Studenti poslijediplomskog studija dentalne medicine Sveučilišta u Zagrebu.

\section{Statistički postupci}

Za statističku analizu podataka korišten je softverski paket SPSS 20 (IBM Corp., Armonk, New York, SAD). Deskriptivnom statističkom analizom određeni su osnovni statistički parametri (učestalosti, medijan, modZMoD/modus, minimalne i maksimalne vrijednosti). Značenje razlika među ispitivanim skupinama procijenjeno je Chi-Squareom ili Fisherovim egzaktnim testovima.

\section{Rezultati}

\section{Rezultati upitnika za 2020. godinu (upitnici TQ i FQ)}

$\mathrm{Na}$ pitanja u upitnicima za studente treće i četvrte godine odgovorilo je njih 79. Nisu pronađene razlike između spolova $(p>0,05)$. Također nije bilo razlike između studenata pretkliničke i kliničke nastave ( $p>0,05)$ osim u motiviranosti - studenti kliničke nastave bili su motiviraniji $(\mathrm{p}<0,01)$. Rezultati su potvrdili da su svi studenti osjećali nelagodu i tjeskobu kad je riječ o akademskom i praktičnom znanju koje

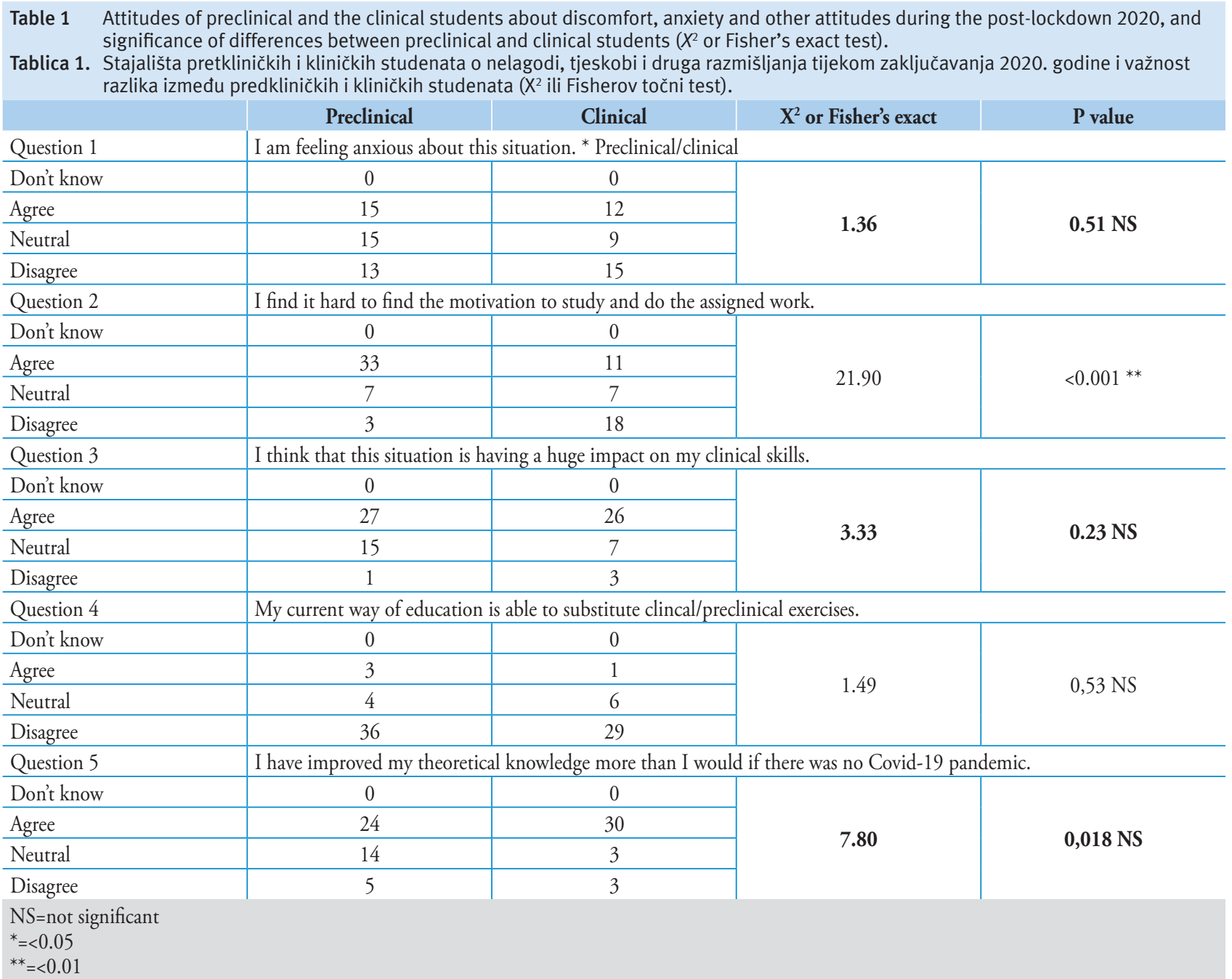



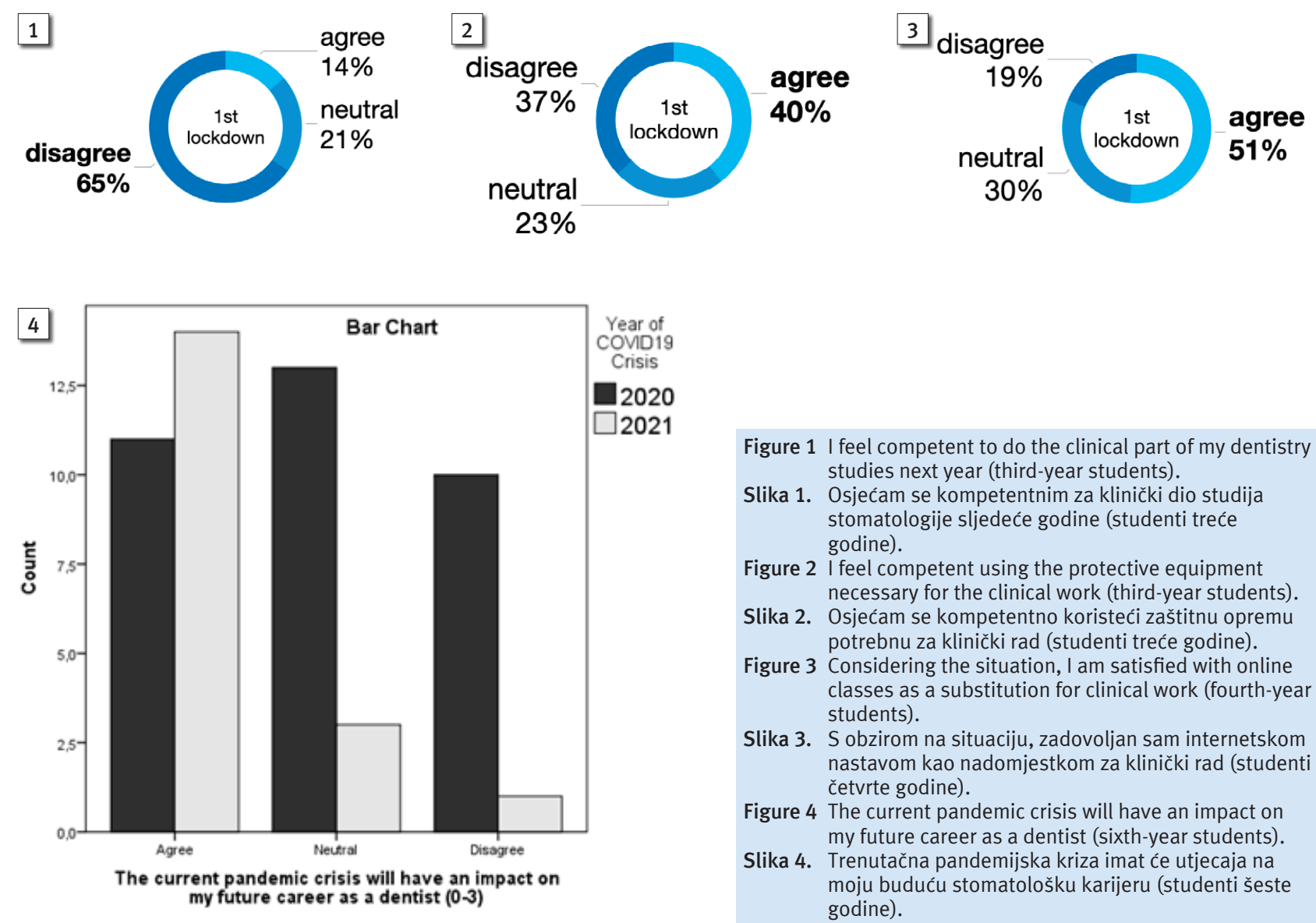
Figure 1 I feel competent to do the clinical part of my dentistry studies next year (third-year students).
Slika 1. Osjećam se kompetentnim za klinički dio studija stomatologije sljedeće godine (studenti treće godine).
Figure 2 I feel competent using the protective equipment necessary for the clinical work (third-year students).
Slika 2. Osjećam se kompetentno koristeći zaštitnu opremu potrebnu za klinički rad (studenti treće godine).
Figure 3 Considering the situation, I am satisfied with online classes as a substitution for clinical work (fourth-year students).
Slika 3. S obzirom na situaciju, zadovoljan sam internetskom nastavom kao nadomjestkom za klinički rad (studenti četvrte godine).
Figure 4 The current pandemic crisis will have an impact on my future career as a dentist (sixth-year students).
Slika 4. Trenutačna pandemijska kriza imat će utjecaja na moju buduću stomatološku karijeru (studenti šeste godine).

confirmed that all students felt discomfort and anxiety towards the future of obtaining their academic knowledge, as well as their practical competencies, which were deprived of during the first lockdown (Table 1). A significant amount $(65 \%)$ of the $3^{\text {rd }}$-year dental students did not feel competent to do future clinical work, with the knowledge they obtained through the course of the first lockdown (Figure 1). The results showed that only $40 \%$ of the $3^{\text {rd }}$-year students felt competent using the protective equipment necessary for the clinical work (Figure 2). During the first lockdown, $51 \%$ of the students from the $4^{\text {th }}$-year felt satisfied with the substitution of clinical exercises with online classes, considering the situation in the world (Figure 3).

Statistical analysis between preclinical and clinical students (AQ Questionnaire) from the 2021 questionnaire

All students answered twelve questions. Their opinions were almost uniform, confirming discomfort and anxiety about their future acceptance of the knowledge and practical skills, as they were deprived of exercises during the closure due to the COVID-19 pandemic (Table 2). The $12^{\text {th }}$ question gathered additional comments and could be translated into qualitative data. Three answers were noted and all of them were satisfactory, e.g. "Lectures are better online because they are recorded and I can rewatch them whenever I need, seminars and preclinical exercises definitely not because students are not well prepared (I would say it's because of loss of motivation) and some professors are frustrated." nisu stjecali tijekom prvog zaključavanja (tablica 1). Znatan broj studenata treće godine dentalne medicine $(65 \%)$ smatrao je da nisu kompetentni za obavljanje budućega kliničkoga rada zbog nedostatka prakse koju su propustili tijekom prvog zaključavanja (slika 1.). Rezultati su pokazali da se samo njih $40 \%$ osjeća kompetentnima koristiti se ZRO-om potrebnim za klinički rad (slika 2.). Tijekom prvog zaključavanja zadovoljnima se osjećalo $51 \%$ studenata četvrte godine zbog zamjene kliničkih vježbi nastavom na daljinu, uzimajući u obzir situaciju u svijetu (slika 3.).

\section{Statistička analiza između pretkliničkih i kliničkih studenata (AQ upitnik) tijekom 2021. godine}

Svi su studenti odgovorili na dvanaest pitanja. Njihova mišljenja bila su gotovo jednaka, što je potvrđivalo nelagodu i tjeskobu u vezi s količinom njihova znanja i praktičnih vještina zbog smanjenog broja vježbi tijekom zatvaranja prouzročenog pandemijom bolesti COVID-19 (tablica 2.).

Dvanaestim pitanjem prikupljeni su dodatni komentari i moglo bi ih se prevesti u kvalitativne podatke. Zabilježena su tri odgovora i svi su bili zadovoljavajući. Evo primjera: Predavanja su bolja kad se održavaju na daljinu jer se snimaju i mogu ih ponovno pogledati kad god mi zatrebaju, a seminari i pretkliničke vježbe nisu jer studenti nisu dobro pripremljeni (rekao bih da je to zbog gubitka motivacije), a neki profesori su frustrirani. 
Table 2 Attitudes of dental students of preclinical and clinical years of study towards discomfort and anxiety during the lockdown in 2021 due to the COVID-19, and the significance of the differences between them ( $X^{2}$ or Fisher's exact test).

Tablica 2. Stajališta studenata stomatologije iz predkliničkih i kliničkih godina studija o nelagodi i tjeskobi tijekom zaključavanja 2021. zbog COVID-19 i važnosti razlika između njih ( $X^{2}$ ili Fisherov točni test).

Preclinical students $\quad$ Clinical students

$\mathrm{X}^{2}$ or Fisher's exact

P value

\begin{tabular}{l|l} 
Question 1 & Compared to the first lock-down at the beginning of the year, I feel less anxious about the COVID-19 situation.
\end{tabular}

Don't know

Agree

Neutral

\begin{tabular}{|c|c|}
\hline 1 & 0 \\
\hline 81 & 19 \\
\hline 14 & 5 \\
\hline
\end{tabular}

Disagree

Question 2

I think that I won't be able to compensate missed clinical work.

Don't know

Agree

Neutral

Disagree

Question 3

Don't know

Agree

Neutral

Disagree

Question 4

Don't know

Agree

Neutral

Disagree

Question 5

\begin{tabular}{|l|l|}
\hline 11 & 1 \\
\hline 22 & 9 \\
\hline 27 & 9 \\
\hline
\end{tabular}

1.96

$0.58 \mathrm{NS}$

Don't know

Agree

Neutral

Disagree

Question 6

27

The School of Dental Medicine, University of Zagreb has organized compensation for the lost preclinical/clinical exercises during the first lock-down.

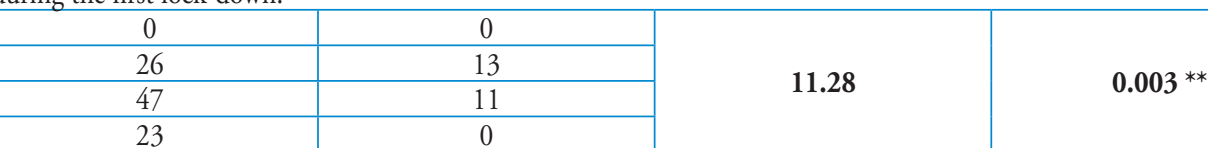

Because of the lost preclinical/clinical exercises during the first lock-down I feel less confident working on patients this year.

\begin{tabular}{l|c|c|c|}
\hline Don't know & 4 & 0 & \multirow{2}{*}{$\mathbf{0 . 6 5}$} \\
\cline { 1 - 3 } Agree & 35 & 10 & \multirow{2}{*}{$\mathbf{0 . 9 8}$ NS } \\
\hline Neutral & 21 & 5 & 9 \\
\hline Disagree & 36 & $\begin{array}{l}\text { I adapted well to the current way of how educational programme (lectures, seminars, preclinical/clinical exercises...) is } \\
\text { being delivered. }\end{array}$
\end{tabular}

Don't know

Agree

Neutral

Disagree

Question 8

being delivered.

Don't know

Agree

Neutral

Disagree

Question 9

Don't know

Agree

Neutral

Disagree

Question 10 0

Due to the current COVID-19 situation I have an impression that I am treating less patients than before.

Don't know

Agree

Neutral

Disagree

Question 11

73

\begin{tabular}{|c|c|}
\hline 17 & 1 \\
\hline 21 & 11 \\
\hline 5 & 6 \\
\hline
\end{tabular}

$0.018^{* *}$

Don't know

Agree

Neutral

Disagree

11

0.59

0.74 NS

I find online lectures/seminars better than those delivered in person.

$\mathrm{NS}=$ not significant

$*=<0.05$

** $=<0.01$

\begin{tabular}{|c|c|}
\hline 0 & 0 \\
\hline 42 & 15 \\
\hline 23 & 4 \\
\hline 31 & 5 \\
\hline
\end{tabular}

I feel competent using the PPE (personal protective equipment) during the preclinical/clinical exercises.

\begin{tabular}{c|c|c|c|}
\hline 17 & 0 & & $\mathbf{6}$ \\
59 & 17 & $\mathbf{6 . 4 6}$ & $\mathbf{0 . 0 3}^{*}$ \\
18 & 7 & & \\
\hline 2 & 0 &
\end{tabular}

feel safe and well protected in the environment of the preclinical/clinical exercises (the rooms are well ventilated; the number of people in the room is minimized...).

\begin{tabular}{|c|c|}
\hline 10 & 0 \\
\hline 71 & 19 \\
\hline 6 & 4 \\
\hline
\end{tabular}

The current pandemic crisis will have an impact on my future career as a dentist.

\begin{tabular}{|c|c|}
\hline 10 & 3 \\
\hline 52 & 10 \\
\hline 13 & 7 \\
\hline 21 & 4 \\
\hline
\end{tabular}


Table 3. Attitudes of students about discomfort and anxiety during the lockdown 2021 and significance of the diferences between gender.

Tablica 3. Stajališta studenata o nelagodi i tjeskobi tijekom zaključavanja 2021. godine i razlika između spola.

\begin{tabular}{l|l|l} 
Male & Female & $\mathrm{X}^{2}$ or Fisher's exact
\end{tabular}

P value

\begin{tabular}{l|l} 
Question 1 & Compared to the first lockdown at the beginning of the year, I feel less anxious about the COVID-19 situation.
\end{tabular}

\begin{tabular}{|c|c|c|c|c|}
\hline Don't know & 0 & 1 & \multirow{5}{*}{1.15} & \multirow{5}{*}{$0.58 \mathrm{NS}$} \\
\hline Agree & 15 & $\frac{1}{05}$ & & \\
\hline Neutral & & o) & & \\
\hline & 4 & 1) & & \\
\hline Disagree & & & & \\
\hline Question 2 & \multicolumn{4}{|c|}{ I think that I won't be able to compensate missed clinical work. } \\
\hline Don't know & 1 & 11 & \multirow{4}{*}{2.54} & \multirow{4}{*}{$0.48 \mathrm{NS}$} \\
\hline Agree & 7 & 34 & & \\
\hline Neutral & 8 & 27 & & \\
\hline Disagree & 3 & 29 & & \\
\hline Question 3 & \multicolumn{4}{|c|}{$\begin{array}{l}\text { The School of Dental Medicine. University of Zagreb has organised compensation for the lost preclinical/clinical exercise } \\
\text { during the first lockdown. }\end{array}$} \\
\hline Don't know & 0 & 0 & \multirow{4}{*}{0.95} & \multirow{4}{*}{$0.62 \mathrm{NS}$} \\
\hline Agree & 8 & 31 & & \\
\hline Neutral & 8 & 50 & & \\
\hline Disagree & 3 & 20 & & \\
\hline Question 4 & \multicolumn{4}{|c|}{$\begin{array}{l}\text { Because of the lost preclinical/clinical exercises during the first lockdown I feel less confident working on patients this } \\
\text { year. }\end{array}$} \\
\hline Don't know & 6 & 22 & \multirow{4}{*}{0.92} & \multirow{4}{*}{$0.81 \mathrm{NS}$} \\
\hline Agree & 7 & 40 & & \\
\hline Neutral & 3 & 21 & & \\
\hline Disagree & 3 & 18 & & \\
\hline Question 5 & \multicolumn{4}{|c|}{$\begin{array}{l}\text { Due to the current COVID-19 situation I have an impression that I am treating less patients than before. (Only for } \\
\text { students working at the clinics) }\end{array}$} \\
\hline Don't know & 4 & 14 & \multirow{4}{*}{1.54} & \multirow{4}{*}{$0.67 \mathrm{NS}$} \\
\hline Agree & 4 & 28 & & \\
\hline Neutral & 3 & 8 & & \\
\hline Disagree & 2 & 10 & & \\
\hline Question 6 & \multicolumn{4}{|c|}{$\begin{array}{l}\text { I believe that the current way of preclinical/clinical exercises and online learning is having a positive effect on my } \\
\text { education. }\end{array}$} \\
\hline Don't know & $\begin{array}{r}1 \\
\end{array}$ & 3 & \multirow{4}{*}{2.18} & \multirow{4}{*}{$0.49 \mathrm{NS}$} \\
\hline Agree & 6 & 39 & & \\
\hline Neutral & 6 & 20 & & \\
\hline Disagree & 6 & 39 & & \\
\hline Question 7 & \multicolumn{4}{|c|}{$\begin{array}{l}\text { I adapted well to the current way of how educational programme (lectures, seminars, preclinical/clinical exercises...) is } \\
\text { being delivered. }\end{array}$} \\
\hline Don't know & & & \multirow{4}{*}{1.69} & \\
\hline Agree & 14 & 76 & & $0.44 \mathrm{NS}$ \\
\hline Neutral & 4 & 12 & & $0.44 \mathrm{NS}$ \\
\hline Disagree & 1 & 13 & & \\
\hline Question 8 & I find online lect & hose & & \\
\hline Don't know & 0 & 0 & & \\
\hline Agree & 9 & 48 & 3.47 & $017 \mathrm{NS}$ \\
\hline Neutral & 7 & 20 & $3.4 /$ & $0.1 / \mathrm{NS}$ \\
\hline Disagree & 3 & 33 & & \\
\hline Question 9 & I feel competent & rotect & he precl & \\
\hline Don't know & 3 & 14 & & \\
\hline Agree & 12 & 64 & 0.41 & $100 \mathrm{NS}$ \\
\hline Neutral & 4 & 21 & 0.41 & $1.00 \mathrm{NS}$ \\
\hline Disagree & 0 & 2 & & \\
\hline Question 10 & $\begin{array}{l}\text { I feel safe and we } \\
\text { number of peopl }\end{array}$ & Iment & 1 exercis & 1 ventilated, the \\
\hline Don't know & 1 & 9 & & \\
\hline Agree & 15 & 75 & 031 & $100 \mathrm{NS}$ \\
\hline Neutral & 2 & 11 & 0.51 & $1.00 \mathrm{NS}$ \\
\hline Disagree & 1 & 6 & & \\
\hline Question 11 & The current panc & ipact & dentist. & \\
\hline Don't know & 1 & 12 & & \\
\hline Agree & 12 & 50 & 498 & $015 \mathrm{NS}$ \\
\hline Neutral & 5 & 15 & 4.98 & $0.15 \mathrm{NS}$ \\
\hline Disagree & 1 & 24 & & \\
\hline $\begin{array}{l}\text { NS=not signi } \\
*=<0.05 \\
* *=<0.01\end{array}$ & & & & \\
\hline
\end{tabular}


"Online learning should exist also after covid."

"I like the concept of online lectures and I think that we should keep ONLINE lectures and (pre)clinical exercises at faculty even when some of the pandemic measures are cancelled. lectures and handouts being uploaded on merlin platforms has been a HUGE help and that's something a lot of subjects didn't do before."

\section{Statistical analysis based on gender (AQ Questionnaire)}

There were no differences between female and male students. Both genders confirmed discomfort and anxiety about the future acceptance of knowledge and practical skills and competences because of closure due to the COVID-19 pandemic (Table 3).

\section{Influence of the pandemic crisis on the future career perspectives ( $A Q$ and $S Q$ Questionnaire)}

There was a significant difference between the opinions of the $6^{\text {th }}$-year students about the influence of the pandemic crisis on their future careers as dentists. In 2020, most students were neutral and disagreed with the mentioned statement, while in 2021 they mostly agreed that COVID-19 will have an impact on their future career $(\mathrm{p}<0,01)$ (Figure 4).

\section{Discussion}

The spread of the COVID-19 pandemic has immediate effect on dental education, forcing universities to cancel all of their in-person activities and to switch to a virtual environment, thus forcing dental students to adapt to new forms of learning and teaching $(3-5,11)$. The delivery of the curricula on the online platform greatly relies on the technical capacity of dental school, students' access to the internet and a possibility to use computers at home, as well as it relies on digital literacy of the University staff $(4,11-13)$. There is not much evidence showing a plausible effect on higher education, however one study does show that there could be some positive effects of COVID-19 on the students' performance (14). According to conclusions of systemic review of Regmi $K$ et al (2020), distance education could enhance learning and performance because of its accessibility and flexibility (15). Several studies have shown that students find e-learning gratifying $(16,17)$. Moreover, it was also reported that both students and professors appreciated e-learning in terms of teacher-student interaction, however, remote teaching cannot replace clinical training (18). When analyzing the first and the second lockdown (2020 and 2021), 51\% of the $4^{\text {th }}$ year dental students were satisfied with the online forms of teaching (Figure 3). More interestingly, during the first lockdown, majority of the participants agreed that they improved their theoretical knowledge more than they would have done if there had not been the COVID-19 pandemic (Table 1). However, during the second lockdown, the downgrade of the students' opinion was noted (Table 2, Table 3). The downgrade of the experience could be explained by the lack of digital literacy of some of the faculty staff and/or students' fatigue of the online forms of teaching and learning $(19,20)$. The Council of European Dentists (CED) does mention in their policy paper that the European dental education insti-
Učenje na daljinu trebalo bi ostati i nakon koronavirusa.

Dopada mi se koncept predavanja na daljinu i mislim da bismo trebali držati on line predavanja $i$ (pret)kliničke vježbe na fakultetu čak $i$ kad se ukinu neke pandemijske mjere. Predavanja i materijali koji se prenose na platformi Merlin bila su VELIKA pomoć $i$ to je nešto što mnogi profesori prije nisu radili.

\section{Statistička analiza na temelju spola (AQ upitnik)}

Nije bilo razlika između studenata i studentica. I jedni i drugi potvrdili su nelagodu i tjeskobu zbog količine znanja i praktičnih vještina te kompetencije zbog zatvaranja tijekom pandemije bolesti COVID-19 (tablica 3.).

\section{Utjecaj pandemijske krize na buduće karijere (upitnici AQ i SQ)}

Znatna je razlika između mišljenja studenata šeste godine o utjecaju pandemijske krize na njihovu buduću stomatološku karijeru. U 2020. većina je bila neutralna i nije se složila sa spomenutom izjavom, a 2021. uglavnom su se složili da će koronavirus utjecati na njihovu buduću karijeru ( $\mathrm{p}<$ 0,01) (slika 4.).

\section{Rasprava}

Šrenje pandemije bolesti COVID-19 neposredno utječe na stomatološko obrazovanje - naime, sveučilišta su bila prisiljena otkazati sve svoje aktivnosti na fakultetima i organizirati nastavu na daljinu pa su se studenti dentalne medicine morali prilagoditi novim oblicima nastave i učenja (3 $-5,11)$. Dostava kurikula na on line platformama uvelike ovisi o tehničkim mogućnostima stomatoloških fakulteta, o pristupu studenata internetu, mogućnosti korištenja računala kod kuće te o digitalnoj pismenosti nastavnika (4, 11 13). Nema mnogo dokaza o utjecaju na visoko obrazovanje, no u jednom istraživanju ističe se da bi moglo biti nekih pozitivnih učinaka bolesti COVID-19 na uspješnost studenata (14). Prema sustavnom pregledu koji su proveli K. Regmi i suradnici 2020., zaključeno je da bi obrazovanje na daljinu zbog svoje pristupačnosti i fleksibilnosti moglo poboljšati učenje i uspješnost (15). U nekoliko studija autori su pokazali da su studenti zadovoljni e-učenjem $(16,17)$. Štoviše, također je istaknuto da su i studenti i profesori cijenili nastavu na daljinu u smislu zajedničke interakcije, no daljinsko poučavanje ne može zamijeniti klinički rad (18). Analizirajući prvo i drugo zaključavanje (2020. i 2021.), 51 \% studenata četvrte godine dentalne medicine bilo je zadovoljno nastavom na daljinu (slika 3.). Što je još zanimljivije, tijekom prvog zaključavanja većina sudionika složila se da su poboljšali svoje teoretsko znanje više nego što bi to učinili da nije bilo pandemije bolesti COVID-19 (tablica 1.). No tijekom drugog zaključavanja zabilježena je promjena mišljenja (tablice 2. i 3.). To bi se moglo objasniti nedostatkom digitalne pismenosti kod nekih nastavnika i/ili zamorom studenata od nastave na daljinu (19, 20). Vijeće europskih stomatologa (engl. Council of European Dentists - CED) u svojim dokumentima o politikama spominje da bi europske ustanove za stomatološko obrazovanje trebale ulagati u prikladnu infrastrukturu kako 
tutions should invest in a suitable infrastructure to ensure the appropriate quality of online education, whilst exploiting the power of technology for learning and teaching. Moreover, students should also be supported (financially, instructive, etc.) to develop better skills in digital health, communication, resilience, advocacy, public health and well-being (21). One should note that not all students might have access to the internet or laptops to work from home (4). Despite the online forms of teaching being acceptable and appropriate to deliver seminars, lectures or non-clinical programmes, dental students worldwide have been deprived of the critical hands-on practice, which is one of the most crucial parts of their education $(4,22)$. Comparing the results from the first lockdown, dental students from Zagreb, are still uncertain whether they will be able to compensate for the missed clinical work (Tables 1-3). According to the paper published by Hattar et al (2021), dental students from the University of Jordan, sensed that they had missed important learning experiences, especially when it comes to the clinical practice and also have felt less involved in following up with distant learning (23). The School of Dental Medicine, University of Zagreb has organized additional preclinical/clinical exercises during the first lockdown as compensation for student terms lost during the lockdown, however only for certain subjects. Furthermore, the University has opened a possibility to volunteer at the University's clinics, during the summer and winter break, as well as during the exam period. The subjects that consist of practical work require interactions in both preclinical and clinical settings; therefore it is not surprising that dental students from Zagreb are still uncertain about their clinical competency (Table, Table 3, 4).

The School of Dental Medicine in Zagreb had to adapt their clinical settings to ensure the safety of staff and students, and most importantly safeguard the continuity of clinical education. During the first lockdown, $40 \%$ of the students felt competent using the PPE, whereas, after the second lockdown, more students have reported they felt competent using the PPE (Figure 2, Table 2, Table 3). Such findings are logical as the students were instructed on how to properly use the PPE. The University has organized the clinical work at the University but has reduced the number of students per group; the groups were cut in half. Consequently, the amount of clinical practice was reduced for an individual student as well. The majority of students reported they felt safe and well protected in the environment of the preclini$\mathrm{cal} /$ clinical exercises (Table 2, Table 3). Despite the efforts of School of Dental Medicine to deliver clinical practice to their students, students still believed that, due to the COVID-19, they were treating fewer patients than before and have shown the concern that the COVID-19 would have an impact on their future career as dentists (Table 2, Table 3, Figure 4). Since patient care was at a halt, academic institutions were concerned about graduating dental students. There have been uncertainties about their clinical competences and their abilities to meet clinical requirements made by the accreditation bodies, as well as the preparedness to provide dental care in the post-COVID-19 era (21). The Dental Schools Council (DCS), which is the representative body for dental schools bi osigurale odgovarajuću kvalitetu internetskog obrazovanja, istodobno iskorišstavajući snagu tehnologije za učenje i poučavanje. Štoviše, studente također treba poduprijeti (financijski, podukom, itd.) u razvoju ili stjecanju boljih vještina u digitalnom zdravlju, komunikaciji, otpornosti, propagiranju, javnom zdravlju i dobrobiti (21).

Treba imati na umu da svi studenti možda nemaju pristup internetu, ni prijenosnim računalima za rad od kuće (4). Iako su mrežni oblici nastave prihvatljivi i primjereni za održavanje seminara, predavanja ili nekliničkih programa, studenti dentalne medicine diljem svijeta lišeni su prijeko potrebne praktične prakse koja je jedan od najvažnijih dijelova njihova obrazovanja $(4,22)$. Uspoređujući rezultate iz prvog zaključavanja, studenti dentalne medicine iz Zagreba još nisu sigurni hoće li uspjeti nadoknaditi propušteni klinički rad (tablice 1-3).

Prema radu koji su objavili Hattar i suradnici 2021., studenti stomatologije na Sveučilištu u Jordanu osjećaju da su propustili važan dio izobrazbe, posebno kada je riječ o kliničkoj praksi, a osjećali su se manje uključeni u praćenju nastave na daljinu (23). Stomatološki fakultet Sveučilišta u Zagrebu organizirao je nadoknadu za izgubljene pretkliničke/kliničke vježbe tijekom prvog zaključavanja, ali samo za određene predmete. Nadalje, fakultet je omogućio volontiranje na klinici tijekom ljetne i zimske stanke te u razdoblju ispita. Predmeti za koje je potreban praktični rad zahtijevaju interakciju u pretkliničkim i u kliničkim uvjetima, zato ne čudi da studenti dentalne medicine iz Zagreba još uvijek nisu sigurni u svoje kliničke sposobnosti (tablice 3. i 4.).

Stomatološki fakultet u Zagrebu morao je prilagoditi kliničku nastavu kako bi se osigurala sigurnost osoblja i studenata i, što je najvažnije, da omogući kontinuitet kliničkog obrazovanja. Tijekom prvog zaključavanja $40 \%$ studenata osjećalo se sposobnima za korištenje zaštitne radne opreme, a nakon drugoga više je njih izjavilo da su sposobni koristiti se tom opremom (slika 2., tablice 2. i 3.). To je i logično jer su studenti educirani kako se pravilno upotrebljava zaštitna radna oprema. Fakultet je organizirao klinički rad u klinici, ali sa smanjenim brojem studenata u grupi. Slijedom toga smanjen je broj sati kliničke prakse i za pojedinog studenta. Većina studenata izjavila je da se osjećaju sigurno i dobro zaštićeno na pretkliničkim/kliničkim vježbama (tablice 2. i 3.).

Unatoč naporima stomatoloških fakulteta da omoguće svojim studentima kliničku praksu, studenti i dalje vjeruju da zbog bolesti COVID-19 obrađuju manje pacijenata nego prije, te su zabrinuti da će koronavirus utjecati na njihovu karijeru (tablice 2. i 3., slika 4.). Budući da je skrb o pacijentima bila prekinuta, pojavila se velika zabrinutost $\mathrm{u}$ akademskim institucijama zbog nesigurnosti jesu li diplomirani studenti dentalne medicine klinički kompetentni i hoće li moći ispuniti kliničke zahtjeve akreditacijskih tijela te jesu li spremni za pružanje stomatološke skrbi u poslijekovidskom razdoblju (21). Vijeće stomatoloških fakulteta (engl. The Dental Schools Council - DSC), koje je predstavničko tijelo za fakultete dentalne medicine u Ujedinjenom Kraljevstvu i Irskoj, u svojem je radu spomenulo da su svi studenti suočeni sa smanjenjem kliničkog iskustva od ožujka 2020. i da će neko vrijeme svoje kliničke vještine stjecati sporije i u manjem 
across the UK and Ireland, have mentioned in their paper that the students in all year cohorts have faced the reduction in clinical experience since March 2020 and may have to acquire the clinical skills in the slower, reduced rate for some time in the future. They are pointing out that this is of big relevance for those who are entering their final years of study and that the increase of the additional clinical exposure is of great importance. To facilitate the opportunity for the additional clinical work they have created the measures that include extending or altering the sessions within the normal working day for dental students and dental teaching staff. According to DSC, dentistry degree programmes in the UK could be extended if the students did not have an opportunity to gain sufficient practical experience to meet the learning outcomes of the curricular programme $(24,25)$. Moreover, the Council of European Dentists' (CED) position is that there is a need to find the balance between in-person and online teaching. They have also called dental institutions to define a set of minimum requirements to be fulfilled by the students so that adequate European dental education is ensured and that the teaching settings should be in line with the minimal clinical requirements expressed in the Professional Qualifications Directive (PQD) (21).

Apart from the missed in-person teaching and the lack of clinical experience, the COVID-19 pandemic created a level of uncertainty and anxiety about future happenings, thus causing an exceeded level of stress among students leading to unfavorable effects on the learning and psychological health of students $(4,26,27)$. Fear and discomfort in 2020, as well as in 2021, were statistically not significantly different between observed groups, but existed in both years (Table 1, Table 2, Table 3). Even before the outbreak of the COVID-19, discomfort and stress were common amongst students entering the student life due to expectations, pressure to study and pass exams (28-30). During the first lockdown, students felt even more anxious than they did during the second lockdown, which could be explained by adaptations to some new forms of teaching, and decreased levels of stress and fear for both their own and for family's health since more information on COVID-19 was available (Table 1, Table 2, Table 3), and vaccination has just begun. Dental Schools in the UK, as reported by the DCS, are aware that dental students, who undertake an already demanding course, have faced challenges and stressors during the pandemic. Therefore, they are investing a lot of effort to support student wellbeing and are striving to provide students with information on any changes to their courses (25). At the School of Dental Medicine, University of Zagreb, there are no additional programmes available that would support mental health of their dental students; however more assessment is needed to measure the wellbeing of dental students.

\section{Conclusions}

The present study showed that the students were uncomfortable by the COVID-19 pandemic crisis during the first lockdown and the second lockdown (2020 and 2021, respectively). The students have adapted well to the new forms of opsegu. Ističe se da je to vrlo važno za one na posljednjim godinama studija i da je prijeko potrebno povećati dodatnu kliničku praksu. Kako bi stvorili mogućnosti za dodatni klinički rad, poduzeli su mjere koje uključuju produljenje ili izmjenu sesija unutar uobičajenoga radnog dana za studente dentalne medicine i nastavno osoblje. Prema DSC-u, studiji dentalne medicine u Ujedinjenom Kraljevstvu mogli bi se produljiti ako studenti nisu mogli steći dovoljno praktičnog iskustva da bi zadovoljili zahtjeve iz kurikula $(24,25)$. Stoviše, stajalište Vijeća europskih stomatologa (engl. Council of European Dentists - CED) potvrđuje da postoji potreba za pronalaženjem ravnoteže između nastave na fakultetu i na daljinu. Također nalažu stomatološkim ustanovama da definiraju minimalne zahtjeve koje studenti moraju ispuniti kako bi se osiguralo odgovarajuće europsko stomatološko obrazovanje i da nastavne postavke trebaju biti u skladu s minimalnim kliničkim zahtjevima iz Direktive o profesionalnim kvalifikacijama (engl. Professional Qualifications Directive - PQD) (21). Osim propuštanja predavanja na fakultetu i nedostatka kliničkog iskustva, pandemija bolesti COVID-19 stvorila je razinu nesigurnosti i anksioznosti zbog budućih događaja te je tako prouzročila prekomjernu razinu stresa kod studenata, što nepovoljno utječe na učenje i psihološko zdravlje $(4,26$, 27). Strah i nelagoda u 2020. i u 2021. godini statistički se nisu znatno razlikovali u promatranim skupinama, ali postojali su tijekom prooga i drugoga zaključavanja (tablice 1., 2. u 3.). Čak i prije pandemije su nelagoda i stres bili česti među studentima koji su mnogo očekivali od studentskoga života, a dočekali su ih pritisak studija i polaganja ispita $(28-30)$. Tijekom prvog zaključavanja studenti su se osjećali tjeskobnije nego tijekom drugoga, što bi se moglo objasniti boljom prilagodbom novim oblicima nastave i smanjenom razinom stresa i straha za vlastito zdravlje i zdravlje obitelji jer je bilo dostupno i znatno više informacija o toj bolesti (tablice 1., 2 i 3.), a počelo je i cijepljenje. Stomatološki fakulteti u Ujedinjenom Kraljevstvu, kako je izvijestio DCS, svjesni su da su se studenti na tom zahtjevnom studiju tijekom pandemije suočavali s izazovima. Zato ulažu mnogo napora da bi podržali dobrobit studenata i nastoje pružiti informacije o svim promjenama u studijskom programu (25). Na Stomatološkom fakultetu Sveučilišta u Zagrebu ne postoje dostupni dodatni programi koji bi poduprli mentalno zdravlje studenata, no potrebna je dodatna procjena o njihovu mentalnom zdravlju.

\section{Zaključak}

Ovo istraživanje pokazalo je da su studenti zbog pandemijske krize tijekom prvoga i drugoga zaključavanja osjećali nelagodu (2020. i 2021. godine). No dobro su se prilagodili novim oblicima hibridne nastave, ali svjesni su da stoma- 
hybrid teaching, however, they are aware that dental education needs practice and clinical exposure, which is something that cannot be delivered online. Despite the striving of the School of Dental Medicine to compensate for the missed clinical exercises, students still feel uncertain about their clinical competence. There was no significant difference between genders, while clinical students were more motivated during the first lockdown. During the second lockdown, preclinical students felt safer but less confident to treat patients.

\section{Conflict of interest}

Authors declare no conflict of interest.

\section{Acknowledgements}

The authors thank professor Hrvoje Brkić, PhD, who gave the idea for this research and offered support during the writing of the paper. We also thank professor Asja Čelebić, $\mathrm{PhD}$, for statistical data analysis, thus contributing to this research.

The results of this paper were presented online at the Innovations in Education Colloquium on May 8, 2021 in Brescia, Italy.

Author's Contributions: M.A., T.U.R. and T.C. designed and planned the study, created the questionnaire and tested it and wrote the manuscript draft. All authors revised and accepted the final manuscript. All authors have read and agreed to the published version of the manuscript. tološka izobrazba treba i kliničku praksu, a to je nešto što se ne može postići nastavom na daljinu. Unatoč nastojanjima Stomatološkog fakulteta da nadoknadi propuštene kliničke vježbe, studenti se i dalje osjećaju nesigurno u vezi sa svojom kliničkom sposobnošću. Nije bilo znatne razlike između spolova. Studenti koji su sudjelovali u kliničkoj nastavi bili su motiviraniji tijekom prvog zaključavanja. Tijekom drugog zaključavanja studenti pretkliničke nastave osjećali su se sigurnije, ali manje samopouzdano u liječenju pacijenata.

\section{Sukob interesa}

Autori nisu bilu u sukobu interesa.

\section{Zahvala}

Autori zahvaljuju profesoru dr. Hrvoju Brkiću koji dao ideju za ovo istraživanje i ponudio podršku tijekom pisanje rada. Također zahvaljujemo profesorici Asji Čelebić za statističku analizu podataka.

Rezultati ovog rada predstavljeni su na međunarodnom skupu "Education Colloquium" održanom online 8. svibnja 2021. u Brescii, Italija

Doprinos autora: M. A., T. U. R. i T. C. - dizajnirali i planirali studiju, kreirali upitnik i testirali ga te napisali nacrt teksta; svi su autori revidirali i prihvatili konačni tekst nakon što ga pročitali i složili se s objavljenom verzijom.

\begin{abstract}
Sažetak
Cilj: Željelo se procijeniti nelagodu i anksioznost studenata dentalne medicine tijekom pandemije bolesti COVID-19 i procijeniti kvalitetu studija u krizi te usporediti subjektivna iskustva studenata pretkliničke i kliničke nastave kad je riječ o predavanjima i vježbama tijekom prvoga i drugoga zaključavanja na Stomatološkom fakultetu Sveučilišta u Zagrebu. Ispitanici i postupci: Istraživanje je provedeno putem mrežnih upitnika, a studenti su ih sastavili 2020. godine za prezentaciju na Kolokviju u Bresciji u Italiji (Brescia Colloquium). Sudionici su bili 120 studenta integriranoga dodiplomskog i diplomskog studija sa Stomatološkog fakulteta Sveučilišta u Zagrebu, a upitnike su ispunjavali u ožujku 2020. i veljači 2021. Statistička analiza podataka obavljena je softverskim paketom SPSS 20 (IBM Corp., Armonk, New York, SAD). Deskriptivna statistička analiza korištena je za određivanje osnovnih statističkih parametara (učestalost, medijan, minimalna i maksimalna vrijednost). Značenje razlika između ispitivanih skupina procijenjeno je Chi-Squareom ili Fisherovim egzaktnim testovima. Rezultati: Svi studenti dentalne medicine osjećali su određenu nelagodu i bili su zabrinuti zbog svoje buduće kompetencije. Razlike među spolovima nije bilo $(p>0,05)$. Tijekom prvog zaključavanja studenti pretkliničke nastave bili su manje motivirani od studenata kliničke nastave $(p<0,01)$. Tijekom drugog zaključavanja ustanovljene su znatne razlike između studenata pretkliničke i kliničke nastave s obzirom na sigurnost, kompetentnost i samopouzdanje kad je riječ o liječenju pacijenata. Zaključak: Pandemija bolesti COVID-19 utjecala je na dobrobit studenata, njihovo učenje i poučavanje na Stomatološkom fakultetu Sveučilišta u Zagrebu. Na studente je pandemija tijekom prvog zaključavanja utjecala više nego tijekom drugoga, jer su se sada dobro prilagodili novim oblicima nastave. No još uvijek nisu sigurni kad je riječ o sposobnosti u kliničkom okružju i budućoj karijeri.
\end{abstract}

Zaprimljen: 26. travnja 2021. Prihvaćen: 6. lipnja 2021.

Adresa za dopisivanje Marta Adam, studentica 5. godine Ulica Jurja Žerjavića 12 tel: +385951992300 marta.adam@hotmail.com

MeSH pojmovi: učenje na daljinu; stomatološki studenti Ključne riječi: COVID-19, studenti dentalne medicine, stomatološka edukacija

\section{References}

1. Wiersinga WJ, Rhodes A, Cheng AC, Peacock SI, Prescott HC. Pathophysiology, Transmission, Diagnosis, and Treatment of Coronavirus Disease 2019 (COVID-19): A Review. JAMA 2020;324(8):782.

2. Ye Z, Zhang Y, Wang Y, Huang Z, Song B. Chest CT manifestations of new coronavirus disease 2019 (COVID-19): a pictorial review. Eur Radiol. 2020;30(8):4381-9.

3. Brkić H. Dental medicine and COVID-19 pandemic. Acta Stomatol Croat. 2020;54(2):118-20.

4. Sahu P. Closure of Universities Due to Coronavirus Disease 2019 (COVID-19): Impact on Education and Mental Health of Students and Academic Staff. Cureus [Internet]. 2020 [cited 2021 May 11]; Available from: https://www.cureus.com/articles/30110-clo- sure-of-universities-due-to-coronavirus-disease-2019-covid19-impact-on-education-and-mental-health-of-students-and-academic-staff

5. Torales J, O’Higgins M, Castaldelli-Maia JM, Ventriglio A. The outbreak of COVID-19 coronavirus and its impact on global mental health. Int J Soc Psychiatry. 2020;66(4):317-20.

6. Coulthard P. Dentistry and coronavirus (COVID-19) - moral decision-making. Br Dent J. 2020 Apr;228(7):503-5.

7. Iyer P, Aziz K, Ojcius DM. Impact of COVID-19 on dental education in the United States. J Dent Educ. 2020;84(6):718-22.

8. Ge Z, Yang L, Xia J, Fu X, Zhang Y. Possible aerosol transmission of COVID-19 and special precautions in dentistry. J Zhejiang UnivSci B. 2020 May;21(5):361-8. 
9. Lazić N, Lazić V, Kolarić B. First three months of COVID-19 in Croatia, Slovenia, Serbia and Federation of Bosnia and Herzegovina: comparative assessment of disease control measures. Infektološki Glas. 2020;40(2):43-9.

10. koronavirus.hr. [cited 2021 May 13]. Available from: https:// www.koronavirus.hr/en

11. Rad FA, Otaki F, Baqain Z, Zary N, Al-Halabi M. Rapid transition to distance learning due to COVID-19: Perceptions of postgraduate dental learners and instructors. PloS One. 2021;16(2):e0246584

12. Kearns LR. Student Assessment in Online Learning: Challenges and Effective Practices. 2012;8(3):11.

13. Webster J, Hackley P. Teaching effectiveness in technology-mediated distance learning. Acad Manage J. 1997;40(6):1282-309.

14. Gonzalez T, de la Rubia MA, Hincz KP, Comas-Lopez M, Subirats L, Fort S, et al. Influence of COVID-19 confinement in students performance in higher education. ArXiv200409545 Cs [Inter net]. 2020 [cited 2021 May 11]; Available from: http://arxiv.org/ abs/2004.09545

15. Regmi K, Jones L. A systematic review of the factors - enablers and barriers - affecting e-learning in health sciences education. BMC Med Educ. 2020;20(1):91.

16. Huynh R. The Role of E-Learning in Medical Education. Acad Med J Assoc Am Med Coll. 2017;92(4):430

17. Ruiz JG, Mintzer MJ, Leipzig RM. The impact of E-learning in medical education. Acad Med J Assoc Am Med Coll. 2006;81(3):20712.

18. Bennardo F, Buffone C, Fortunato L, Giudice A. COVID-19 is a challenge for dental education-A commentary. Eur J Dent Educ Off Assoc Dent Educ Eur. 2020;24(4):822-4.

19. Schlact I. Headaches, exhaustion, and more screen time: Penn students are worn down by online learning [Internet]. [cited 2021 May 11]. Available from: https://www.thedp.com/article/2020/09/zoom-fatigue-online-classes-penn-2020

20. Reddy P, Chaudhary K, Sharma B, Chand D. Contextualized gamebased intervention for digital literacy for the Pacific Islands. Educ Inf Technol. 2021;1-28.

21. Council of European Dentists. Policy. CED Statement - Safe and effective Dental Education during the COVID-19 pandemic. Available online: https://cedentists.eu/library/policy.html (Accessed 15 April 2021.)
22. Afrashtehfar KI, Assery MK. From dental science to clinical prac tice: Knowledge translation and evidence-based dentistry principles. Saudi Dent J. 2017;29(3):83-92.

23. Hattar S, AlHadidi A, Sawair FA, Alraheam IA, El-Ma'aita A, Wahab FK. Impact of COVID-19 pandemic on dental education: online experience and practice expectations among dental students at the University of Jordan. BMC Med Educ. 2021;21(1):151.

24. Dental Schools Council (DSC). Implications for Undergraduate Dental Education and Clinical Training as a consequence of the COVID-19 Public Health Emergency. Available online https:// www.dentalschoolscouncil.ac.uk/publications/ (Accessed 29 April 2021)

25. Dental Schools Council (DSC). The impact of the pandemic on dental education, training and foundation training - FAQs for den tal students. Available online https://www.dentalschoolscouncil. ac.uk/publications/ (Accessed 29 April 2021)

26. Shock, Fear, and Fatalism: As Coronavirus Prompts Colleges to Close, Students Grapple With Uncertainty [Internet]. The Chron icle of Higher Education. 2020 [cited 2021 May 11]. Available from: https://www.chronicle.com/article/shock-fear-and-fatalism-as-coronavirus-prompts-colleges-to-close-students-grapplewith-uncertainty

27. Al-Rabiaah A, Temsah M-H, Al-Eyadhy AA, Hasan GM, Al-Zamil F, Al-Subaie S, et al. Middle East Respiratory Syndrome-Corona Virus (MERS-CoV) associated stress among medical students at a university teaching hospital in Saudi Arabia. J Infect Public Health. 2020;13(5):687-91.

28. Halboub E, Alhaij MN, AlKhairat AM, Sahaqi A-AM, Quadri MFA Perceived Stress among Undergraduate Dental Students in Relation to Gender, Clinical Training and Academic Performance. Acta Stomatol Croat. 2018 Mar;52(1):37-45.

29. Alhajj MN, Khader Y, Murad AH, Celebic A, Halboub E, Márquez $J R$, et al. Perceived sources of stress amongst dental students: A multicountry study. Eur J Dent Educ Off J Assoc Dent Educ Eur. 2018 Nov;22(4):258-71.

30. Laktić M, Kuftinec K, Čelebić A, Kovačić I, Alhajj MN, Kiršić SP. Psychometric Properties of the Croatian Language Version of the Dental Environment Stress Questionnaire on Dental Medicine Students. Acta Stomatol Croat. 2017 Sep;51(3):188-94. 